\title{
Prevalence and geographic range of Nadelspora canceri (Microspora) in Dungeness crab Cancer magister
}

\author{
Richard K. Childers ${ }^{1, *}$, Paul W. Reno ${ }^{2, * *}$, Robert E. Olson ${ }^{1}$ \\ ${ }^{1}$ Department of Fisheries and Wildlife, ${ }^{2}$ Department of Microbiology, Coastal Oregon Marine Experiment Station and \\ Laboratory for Fish Disease Research, Oregon State University, Hatfield Marine Science Center, Newport, \\ Oregon 97365-5296, USA
}

\begin{abstract}
The prevalence and geographic distribution of Nadelspora canceri, a recently described microsporidian parasite of the Dungeness crab Cancer magister, was studied and prevalences were analyzed by sex and size of host crab and date of collection. Nadelspora canceri was widely distributed along the United States Pacific Coast in estuaries from Bodega Bay, California, to southern Washington. Prevalence of the parasite was high in crabs from most estuaries sampled, ranging from a low of $0.4 \%$ (Gray's Harbor, Washington) to $41.2 \%$ (Tillamook Bay, Oregon) with an overall mean of $14 \%$. The parasite also occurred offshore of California and Oregon, but was not found in Puget Sound, Washington or in Glacier Bay, southeastern Alaska. The prevalence of infection in crabs captured in the open ocean was low $(0.3 \%)$, and in crabs taken from nearshore at estuary mouths it was intermediate between estuarine and open-ocean levels. The infection was most prevalent $\{22.4 \%)$ in 2 yr old crabs (13 cm carapace width) and males had approximately 2.5 times higher rate of infection than did females (10.7 vs $3.3 \%$ ). No significant annual or seasonal variations in infection prevalence were detected.
\end{abstract}

KEY WORDS: Microsporidian - Dungeness crab Prevalence - Geographic range - Nadelspora canceri

\section{INTRODUCTION}

Microsporidians are among the most common and most pathogenic of crustacean disease agents (Couch 1983, Sparks 1985) and are especially well documented among the decapods (Sindermann 1990). Most microsporidians of decapods infect muscle tissue causing a white discoloration on gross examination and muscle destruction. Sparks (1985) and Sindermann (1990) have reviewed decapod microsporidiosis.

Although microsporidian parasites have been reported to infect a variety of brachyuran crabs (Sprague 1965, 1970, 1977a, b, Morado \& Sparks 1988, Overstreet 1988), little information has been reported on the geographic range or infection prevalences in crab populations.

\footnotetext{
- Current address: Point No Point Treaty Council, 7999 NW Salish Lane, Kingston, Washington 98346, USA

•-E-mail: renop@ccmail.orst.edu
}

A microsporidian parasite, Nadelspora canceri, infecting Dungeness crabs Cancer magister has recently been described (Olson et al. 1994). This parasite has unusual needle-shaped spores $1 \sim 10 \times$ $<0.25 \mu \mathrm{m}$ ) and is a new genus and species within the new family Nadelsporidae. In initial observations, parasite prevalence levels in Alsea Bay, OR, USA, were approximately $20 \%$, unusually high when compared to other reports of decapod microsporidians (Overstreet \& Whatley 1975, Olson \& Lannan 1984). In contrast, crabs taken from Yaquina Bay, OR $(24 \mathrm{~km}$ north of Alsea Bay) had prevalence levels of approximately $1 \%$.

This study was designed to determine the prevalence of Nadelspora canceri in Dungeness crabs over a large portion of the host geographic range from California to Alaska (U.S. Pacific Coast). Crabs were sampled from estuaries, embayments, near the entrances to estuaries, and offshore. In addition, the relationship between crab sex/size and parasite prevalence was 
investigated. Data were also collected to determine if there was seasonal or annual variation in parasite prevalence.

\section{MATERIALS AND METHODS}

Collection of crabs. Dungeness crabs were usually collected with baited crab rings and pots near high tide during daylight. Rings were lined with $0.6 \mathrm{~cm}$ nylon mesh to allow capture of juvenile crabs $(\leq 1.0 \mathrm{~cm})$ as well as larger crabs. Some Yaquina Bay samples were collected in a $4.8 \mathrm{~m}$ semiballoon otter trawl lined with a $0.6 \mathrm{~cm}$ nylon mesh cod end. Crabs were also collected aboard commercial crabbing vessels offshore in commercial crab pots, some of which were lined with nylon mesh as above to trap smaller specimens. Samples were also collected just outside the entrances to Alsea Bay and Tillamook Bay, OR, using nylon-lined crab pots. Further samples were collected from seafood processing plants in Newport, OR. These crabs were caught by commercial crabbing vessels from Tillamook Bay $\left(45.5^{\circ} \mathrm{N}, 123.87^{\circ} \mathrm{W}\right)$ to the Siuslaw River estuary $\left(44.0^{\circ} \mathrm{N}, 124.07^{\circ} \mathrm{W}\right)$ within $10 \mathrm{~km}$ of shore. All crabs examined at the processing plants consisted of male crabs, greater than $15.5 \mathrm{~cm}$ carapace width (CW).

The carapace width of each crab was measured to the nearest millimeter just anterior to the 10 th anterolateral spine and the sex recorded for crabs $>3.0 \mathrm{~cm}$ $\mathrm{CW}$. Crabs $\leq 3.0 \mathrm{~cm} \mathrm{CW}$ could not be accurately sexed.

The presumptive presence or absence of microsporidian infection was determined by gross examination of the muscle seen through the periarticular membrane at the base of each thoracic appendage. Muscle of infected crabs appeared white and opaque in contrast to the translucent appearance of uninfected crab muscle. An appendage was removed from all crabs which appeared grossly infected and examined by phase contrast microscopy at $400 \times$ to confirm the presence of the morphologically unique Nadelspora canceri spores (Olson et al. 1994). Muscle tissue from 500 grossly uninfected crabs was also examined microscopically to test the accuracy of preliminary diagnosis based on the absence of gross signs of disease. In no instance did grossly negative crabs contain $N$. canceri spores. Crabs collected from Alsea Bay were taken to the holding facility at the Hatfield Marine Science Center, Newport, for further examination and disposal. Crabs collected from all other locations were released after removing a muscle sample from those that appeared infected.

Collection sites. Crabs were collected between June 1990 and June 1994 from Pacific Northwest estuaries and Puget Sound, WA, as listed in Fig. 1. In addition, samples were collected from Glacier Bay, Alaska, in

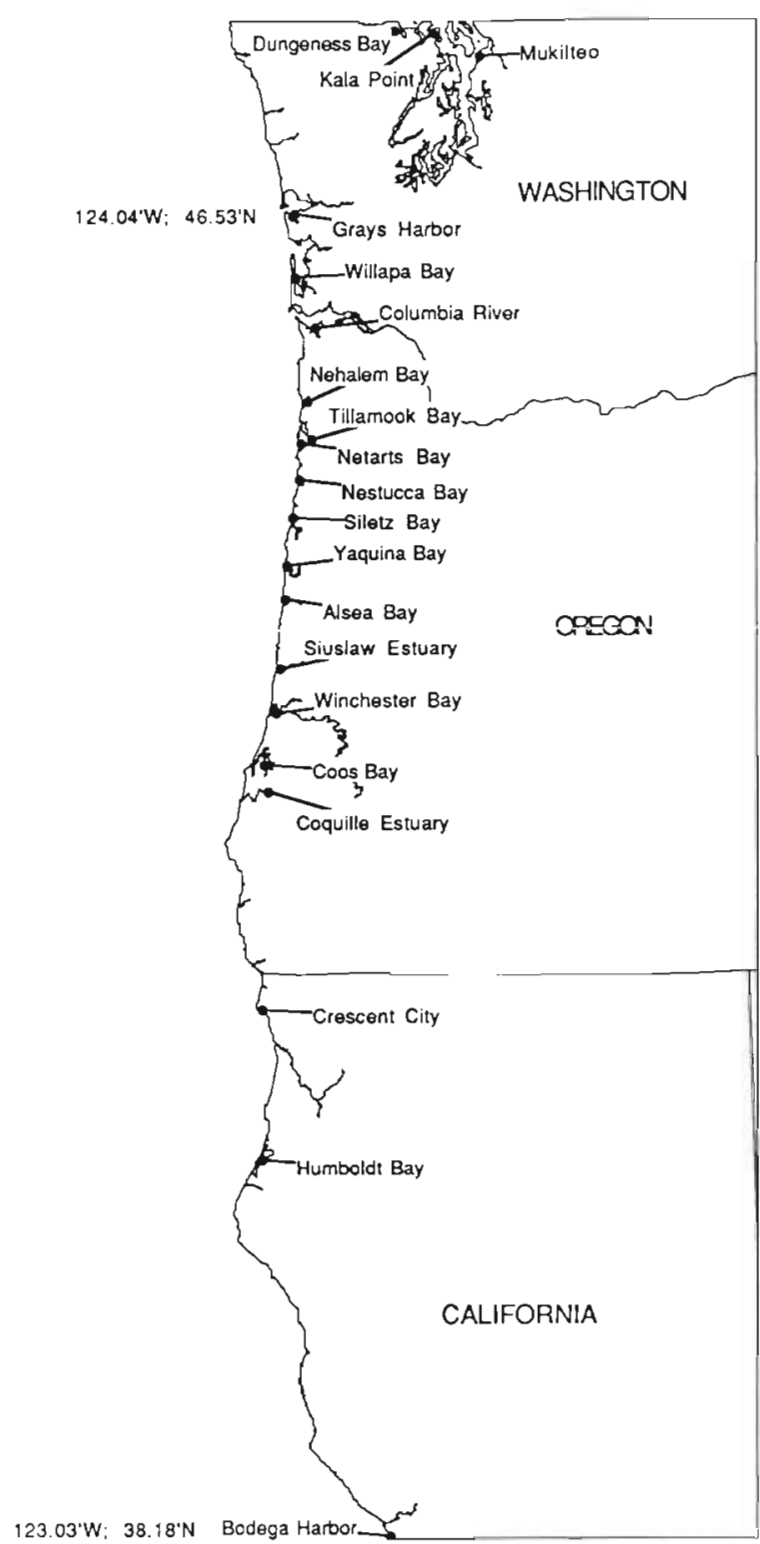

Fig. 1. Locations of sampling sites from which Dungeness crabs were collected for determination of Nadelspora canceri prevalence

September 1994 by personnel from the University of Alaska, Fairbanks.

Evaluation of seasonal effects. Alsea Bay was the site of repeated sampling without replacement to examine seasonal variations in infection levels. The area sampled was restricted to approximately $1 \mathrm{~km}$ northeast and southwest of the US Highway 101 bridge (Fig. 2). Crabs were collected each calendar month beginning in October 1991 and continuing through June 1994. Eleven samples were taken from Yaquina Bay on approximately a quarterly basis during the same period. 


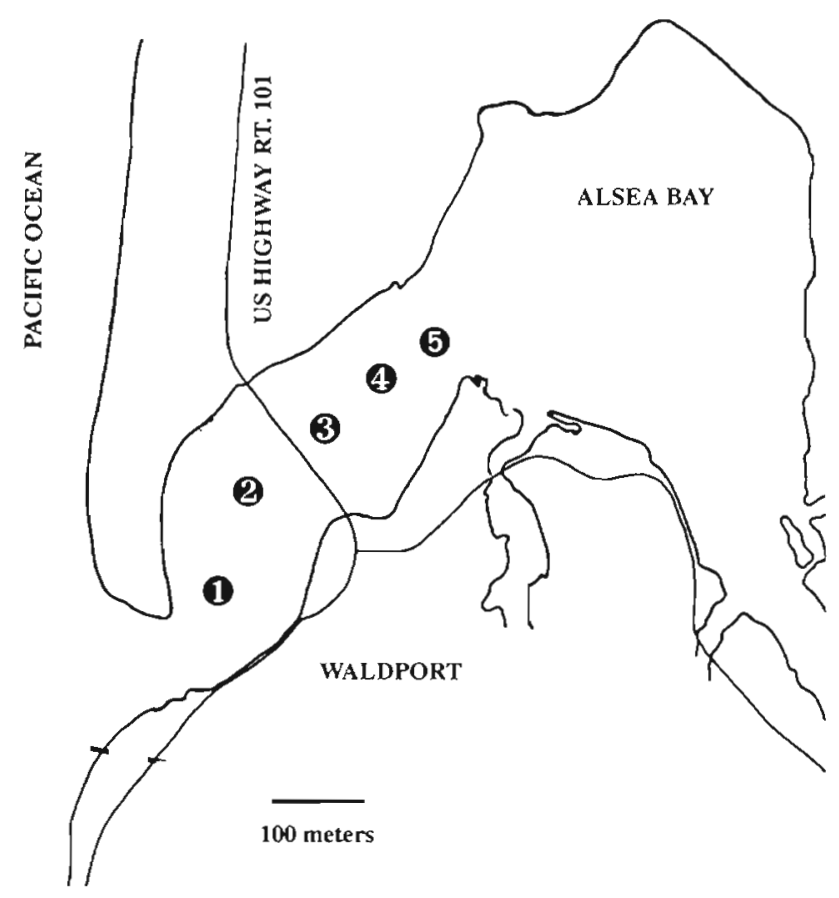

Fig. 2. Sites in Alsea Bay from which crabs were collected on a monthly basis for approximately 3 yr Numbers indicate approximate sites of collection

Statistical analysis. The data on the occurrence of the microsporidian parasite were analyzed using a logistic regression model for binomial proportions. Analyses were carried out using the Statistica-Mac application (Statsoft Corp., Tulsa, OK). Parasite prevalence (proportion of crabs infected with Nadelspora canceri) was used as a response variable in the model. The independent variables, which were treated as classification variables in the model, were CW, sex and sample month. The size variable was created by grouping crabs within each sample into $1 \mathrm{~cm} C W$ increment size classes. A logit transformation of the response variable was used to linearize the relationship between the parasite prevalence and the independent variables (Healy 1988, Atkin et al. 1989). The error distribution in the model was assumed to be binomial. A goodness of fit test was used to determine if the relationship between the response variable and the independent variables was statistically significant.

\section{RESULTS}

\section{Geographic range and prevalence of Nadelspora canceri in estuaries and embayments}

A total of 12656 Dungeness crabs was examined from the locations listed in Table 1 and microsporidian infections were detected in 1134 (9.0\%) crabs. Within the geographic range in which the parasite was detected (southern Washington to northern California), the prevalence was $14.0 \%$. There was substantial variability in the prevalence of Nadelspora cancer among the sampling sites, ranging from a low of $0.44 \%$ at Gray's Harbor, WA, to $41.4 \%$ at Tillamook Bay (Table 1). The overall infection rate of crabs from Alsea Bay which was sampled at monthly intervals for nearly 3 yr was $19.2 \%$. In all but 3 cases, microscopic examination of muscle tissue from the grossly infected crabs confirmed the presence of $N$. Canceri spores. In the 3 individuals (2 from Puget Sound, 1 from Winchester Bay) in which the muscle opacity was not a result of $N$. canceri infection, an undescribed microsporidian from the collective genus Microsporidium was detected. Of the crabs that were categorized as diseased based upon gross examination, 26 exhibited a slight white streaked appearance rather than the more commonly observed white, opaque muscle. When examined microscopically, all of the crabs with white streaks in the muscle were found to be infected with $N$. canceri in the early stage of the infection (Olson et al. 1994). Microscopic examination of 500 crabs that were collected from Alsea Bay and categorized macroscopically as uninfected revealed no microsporidian spores

Table 1 Nadelspora canceri infecting Cancer magister. Prevalence of parasites in Dungeness crabs in estuaries and embayments of the Pacific Coast of the United States. Samples were collected by trawl or in crab pots, visually examined for the presence of muscle abnormalities and confirmed as $N$. canceri by microscopic examination

\begin{tabular}{|lrrc|}
\hline Sample site & $\begin{array}{c}\text { No. } \\
\text { sampled }\end{array}$ & $\begin{array}{c}\text { No. } \\
\text { infected }\end{array}$ & $\begin{array}{c}\text { Percentage } \\
\text { infected }\end{array}$ \\
\hline Bodega Bay, CA & 4 & 1 & 25 \\
Humboldt Bay, CA & 171 & 25 & 14.6 \\
Crescent City Harbor, CA & 33 & 0 & 0 \\
Coquille Estuary, OR & 228 & 7 & 3.1 \\
Coos Bay, OR & 264 & 28 & 10.6 \\
Winchester Bay, OR & 147 & 8 & 5.4 \\
Siuslaw Estuary, OR & 203 & 3 & 1.5 \\
Alsea Bay, OR & 3600 & 690 & 19.0 \\
Yaquina Bay, OR & 1915 & 37 & 2.0 \\
Siletz Bay, OR & 45 & 4 & 8.9 \\
Nestucca Bay, OR & 46 & 4 & 8.7 \\
Netarts Bay, OR & 499 & 170 & 34.1 \\
Tillamook Bay, OR & 244 & 101 & 41.4 \\
Nehalem Bay, OR & 211 & 30 & 14.2 \\
Columbia River & 163 & 3 & 1.8 \\
Willapa Bay, WA & 303 & 21 & 6.9 \\
Gray's Harbor, WA & 453 & 2 & 0.44 \\
Dungeness Bay, WA & 215 & 0 & 0 \\
Kala Pt., WA & 131 & 0 & 0 \\
Mukilteo, WA & 200 & 0 & 0 \\
Glacier Bay, AK & 3581 & 0 & 0 \\
Total & 12656 & 1134 & 9.0 \\
& & & \\
\hline
\end{tabular}


Samples of Dungeness crab were taken from Bodega Bay, CA, in the south to Glacier Bay, AK, in the north, encompassing a large portion of the geographic range of the species. Twenty-one sites were sampled and the parasite was detected in crabs from all sites except for Crescent City Harbor, CA, 3 sites in Puget Sound, and Glacier Bay. The northernmost site from which infected crabs were detected was Gray's Harbor. Within the range in which the parasite was found, there was no significant relationship between the geographic latitude (i.e. north to south) from which the samples were taken and the prevalence level of the disease $\left(\mathrm{r}^{2}=\right.$ 0.01 ), although the prevalence was low from the Washington estuaries sampled. Sampling of crabs from nonestuarine areas of Puget Sound (546 crabs) and Glacier Bay (3581 crabs) failed to detect the parasite (Table 1 ).

\section{Parasite prevalence in crabs collected offshore and nearshore}

The results of examining large, male crabs collected by commercial crabbers, crabs of various sizes collected offshore, and crabs collected near the entrances to Alsea and Tillamook Bays are given in Table 2. Adult male Dungeness crabs $>15 \mathrm{~cm} C W$ which had been harvested commercially were examined at seafood processing plants. Of 9317 crabs examined, 28 were found to be infected with Nadelspora canceri $10.3 \%$ prevalence). The prevalence of $N$. canceri in crabs of all sizes collected offshore was $0.26 \%$.

The parasite prevalence in crabs collected near estuary entrances was more than 10 -fold lower than in the estuaries themselves (1.2 vs $19.1 \%$, Alsea; 3.1 vs $41.4 \%$, Tillamook).

Of a total of 85 crabs with gross signs of microsporidian infection collected offshore and nearshore, 12 were infected with the Microsporidium sp.

\section{Relationship between the prevalence of Nadelspora canceri and crab sex and size}

The relationship between crab sex and size and Nadelspora canceri infection rate was analyzed for estuarine crabs $>3.0 \mathrm{~cm} \mathrm{CW}$ from geographic areas where the parasite was detected. Of the 8078 crabs sampled from these areas, 59.8\% were male and $40.2 \%$ female $_{i}$ in some instances, crabs were not sexed and were not therefore included in this analysis. Fourteen percent of the crabs were infected; of these, $10.7 \%$ were males and $3.3 \%$ were females (Table 3 ). The difference in parasite prevalence between sexes was highly significant $\left(\chi^{2}=152.3,1 \mathrm{df}, \mathrm{p}<0.000001\right)$. The odds ratio for males infected compared to females infected was 2.45; that is, males were 2.45 times more likely to be infected than females.

Table 3. Nadelspora canceri infecting Cancer magister. Two by two contingency table of sex of $N$. canceri-infected and uninfected Dungeness crabs (percentage of total in parentheses). Only crabs which could be accurately sexed $(>3.0 \mathrm{~cm}$ carapace width) are included

\begin{tabular}{|lrcc|}
\hline Infection & Male & Female & Total \\
\hline No & $3969(49.1)$ & $2980(36.9)$ & $6949(86.0)$ \\
Yes & $864(10.7)$ & $265(3.3)$ & $1129(14.0)$ \\
Total & $4833(59.8)$ & $3245(40.2)$ & $8078(100)$ \\
\hline
\end{tabular}




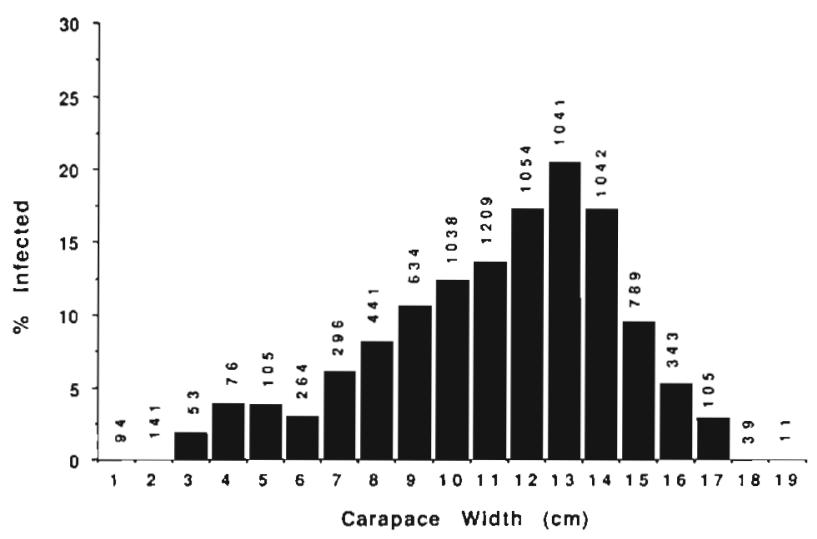

Fig. 3. Nadelspora canceri infecting Cancer magister. Prevalence of parasites in Dungeness crabs when grouped in $1 \mathrm{~cm}$ carapace width intervals. Values above bars represent total number of crabs sampled from that size interval. In some instances, crabs collected from Alsea and Yaquina Bays and Gray's and Willapa Harbors were not measured and are not included in the data in this figure

Of the 18 crabs of various sizes collected offshore in which Nadelspora canceri was detected, none was female. By contrast, for crabs collected in nearshore areas near Alsea and Tillamook Bays, the parasite was detected at about the same level in males as in females.

There was a significant variation of infection rates in different size classes of crabs (Fig. 3). The prevalence of Nadelspora canceri infection in crabs was approximately normally distributed when plotted by CW of the crab, with the highest prevalence occurring in crabs within the 12 to $13 \mathrm{~cm} \mathrm{CW}$ interval; there was a slight positive skewness in the distribution toward larger size classes. Although crabs up to $18.9 \mathrm{~cm} \mathrm{CW}$ were collected during the study, no crabs greater than $16.5 \mathrm{~cm} \mathrm{CW}(\mathrm{CW}>16.5 \mathrm{~cm}, n=95)$ were found to be infected with the parasite. Crabs as small as $0.7 \mathrm{~cm} \mathrm{CW}$ were collected, and no crabs smaller than $2.4 \mathrm{~cm}$ were infected ( $\mathrm{CW}<2.4 \mathrm{~cm}, \mathrm{n}=$ 253). Analysis of the data from the prevalence level versus $\mathrm{CW}$ indicated that the increase of prevalence of the parasite in the 7 to $14 \mathrm{~cm}$ range size classes was entirely due to an increase in the disease prevalence in male crabs (Fig. 4). The infection prevalence rate in females remained between 6 and $10 \%$ while the rate in males ranged from 6 to $26 \%$, peaking in the 12 to $13 \mathrm{~cm}$ size class.

\section{Prevalence of Nadelspora canceri with time/season}

During the 4 yr study period, samples were collected during all months of the year. Monthly sampling was carried out in Alsea Bay, and sampling in Yaquina Bay was done approximately quarterly. Crabs from other areas were generally sampled once or twice during the course of the study. Over the 4 yr, there was no significant change in the overall prevalence level of Nadelspora canceri infection at any sample site examined (Table 4). The $\chi^{2}$ value for these data was 6.81 (32 df, $\mathrm{p}=0.1465)$

Analysis of the data from all sites by month was carried out. Most of the crabs examined were from Alsea and Yaquina Bays $(61 \%)$, with the balance from 15 other sites where the parasite was detected. In Alsea Bay, which was sampled monthly for more than 3 yr, the monthly prevalence ranged from $9.3 \%$ in September to $27.6 \%$ in December; there was no seasonal trend in the prevalence level of the parasite. For all bays and estuaries in which Nadelspora canceri was detected, the range of prevalence by month was $6.1 \%$ in August to $24.1 \%$ in January; there was no seasonal or yearly

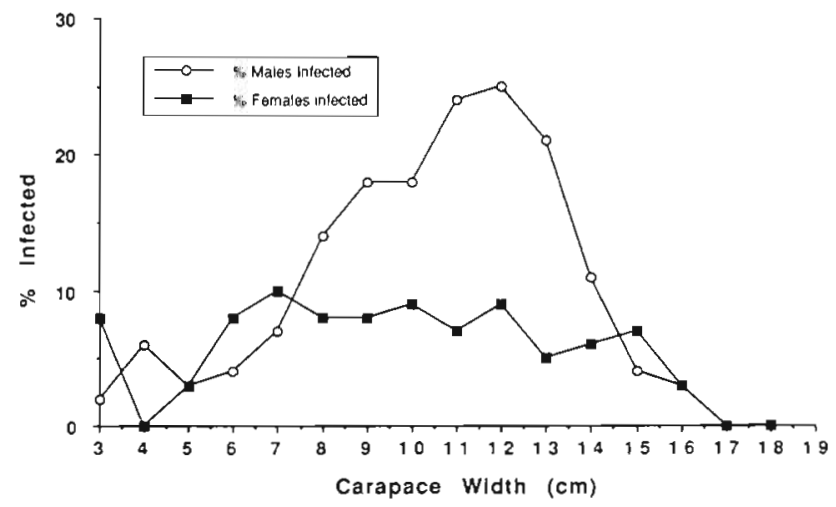

Fig. 4. Nadelspora canceri infecting Cancer magister. Prevalence of parasites in male and female Dungeness crabs when grouped in $1 \mathrm{~cm}$ carapace width intervals

Table 4. Nadelspora canceri infecting Cancer magister. Prevalence of infection during a 4 yr sampling period. Numbers in parentheses indicate the percentage of positives for each year (Infected) or percentage of all crabs collected (Total). Data for crabs collected from Puget Sound and Glacier Bay are not included since the parasite was not detected at these sites

\begin{tabular}{|lcccccc|}
\hline & 1990 & 1991 & 1992 & 1993 & 1994 & Total \\
\hline Uninfected & 395 & 290 & 3178 & 2241 & 1291 & 7395 \\
Infected & $54(12.0)$ & $51(15.0)$ & $449(12.4)$ & $363(13.9)$ & $217(14.3)$ & 1134 \\
Total & $449(5.2)$ & $341(3.8)$ & $3627(42.5)$ & $2604(30)$ & $1508(17.6)$ & 8524 \\
\hline
\end{tabular}




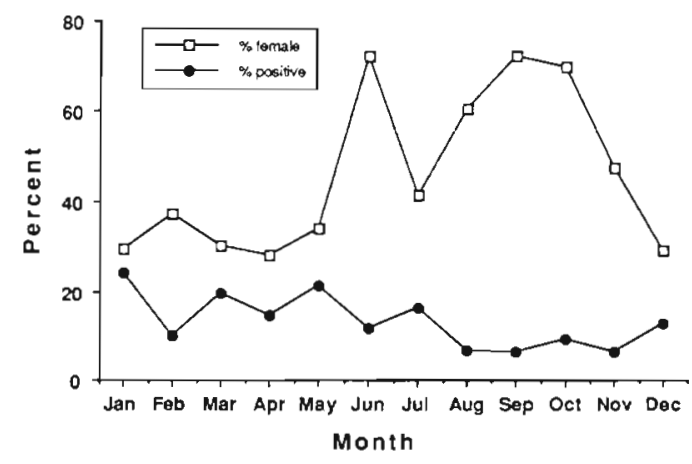

Fig. 5. Nadelspora canceri infecting Cancer magister. Monthly parasite prevalence and proportion of crabs that were female collected from 1990 to 1994, all sites

trend in $N$. canceri prevalence (for all bays: adjusted $r^{2}=0.006$; for Alsea Bay: adjusted $r^{2}=0.07$ ). There was a much higher proportion of female crabs collected during late summer and early fall than at other times of the year (Fig. 5). Maximum likelihood analysis indicated a highly significant difference between the model including month only and the model including month $\times \operatorname{sex}\left(\chi^{2}=293.25,1 \mathrm{df}, \mathrm{p}<0.00001\right)$, indicating that much of the variability in prevalence was associated with the lower prevalence of the pathogen in female crabs.

\section{DISCUSSION}

The microsporidian Nadelspora canceri was found in Dungeness crabs Cancer magister at high prevalence in estuaries and embayments (overall level was $14 \%$ ) throughout a major portion of the geographic range of the host. It was detected at much lower levels in crabs from offshore locations, and at intermediate levels in samples taken just outside of the entrances to Alsea Bay and Tillamook Bay. The parasite was not detected in crabs taken in Puget Sound or Glacier Bay. The only gross sign of disease, white, opaque muscle tissue visible through the proximal periarticular membrane of the appendages, while not pathognomic is highly correlated with $N$. canceri infection. In 1134 infected crabs collected from the estuaries sampled in this study within the range of $N$. canceri, only a single individual from Winchester Bay was infected with another agent: an undescribed microsporidian species. However, this second microsporidian was detected more frequently in samples from the open ocean. Since $N$. canceri is readily diagnosed by phase contrast microscopy, removal of an appendage for examination is all that is required for confirmation of the type of microsporidian infecting an individual. It is also possible to diagnose the disease by inserting a syringe needle through the periarticular membrane and removing a small muscle biopsy sample. Since the parasite is present in great profusion in the muscle tissue, sufficient material is obtained to make a diagnosis without the necessity of removing an appendage.

Nadelspora canceri was found as far south as Bodega Bay near the southern extent of the host Dungeness crab range. In contrast, the parasite was detected only as far north as the Gray's Harbor estuary in Washington (latitude $46.88^{\circ} \mathrm{N}$ ), although the northern range of the Dungeness crab extends to approximately $62^{\circ} \mathrm{N}$ latitude (Pauley et al. 1986).

More than 4000 crabs were collected from 2 areas north of Gray's Harbor (546 from Puget Sound and 3581 from Alaska). If the parasite is present in these areas, its prevalencc must be quite lovi. Using calcuications derived from the binomial distribution, at a $95 \%$ confidence level, if 3500 crabs were sampled from 1 area such as Glacier Bay, the prevalence of Nadelspora canceri in the population was likely to be less than $0.0015 \%$; likewise, for a sample size of 546 from Puget Sound this would correspond to a likely prevalence of less than $0.55 \%$. In addition, Morado (1993) had examined nearly 2000 Dungeness crabs from the area of the San Juan Islands, WA, while studying a ciliate disease, but failed to note the presence of any agents resembling $N$. canceri. Data gathered from samples of crabs from the open ocean of $f$ the coast of Oregon (Table 2) indicate that the parasite prevalence is much lower in the ocean (mean $0.3 \%$ ) than in embayments or estuaries. Thus, it is possible that the sample size for crabs taken from Puget Sound was too small to detect $N$. canceri at levels that were found in the open ocean. If the parasite was indeed present in crabs taken from Glacier Bay, the prevalence would have to have been $100-$ fold less than that detected in open ocean crabs off the Oregon coast. The factors that apparently restrict the parasite distribution to the southern part of the host geographic range are unknown. It is possible that the parasite requires estuarine water temperatures that are higher than those that characterize the open Pacific Ocean and deep embayments, but this possibility has not been explored.

Within the observed range, there was a wide variation in the prevalence of Nadelspora canceri, ranging from 1.4 to $42 \%$ at individual collecting sites, but no correlation between latitude and prevalence. Nor was there any indication of a correlation between the prevalence of infection between individual estuaries and those nearby. For example, Alsea Bay had a mean prevalence of $19 \%$ while Yaquina Bay, the next nearest embayment $24 \mathrm{~km}$ to the north, had a mean rate of $2 \%$. These data suggest that the parasite, and perhaps the crabs, tend to move little between estuaries. This is supported by the data accrued from the sampling near 
the entrances to Tillamook Bay and Alsea Bay. The levels of the microsporidian found within $1 \mathrm{~km}$ of the entrances to these bays were approximately 10-fold less than those detected in crabs within the bays. If extensive movement between the bays and the open ocean were occurring, the parasite prevalence in the bays would be reduced due to the influx of crabs from the open ocean where the parasite prevalence is 100 fold lower than that observed in bays. Perhaps this is what is occurring in bays in which the prevalence is low, such as Yaquina Bay or Gray's Harbor, but not in Tillamook or Alsea Bays. If it is assumed that this parasite has been present in Dungeness crab populations for an extended period, and there was extensive movement of crabs among estuaries via the open ocean, then the parasite levels should be fairly homogenous among the estuaries. Other factors, however, may be involved in this phenomenon. For example, movement in and out of estuaries may differ from bay to bay and/or recruitment rates may differ from bay to bay. Another possibility is that an alternative host (Andreadis 1985) is required in the cycle but is not distributed throughout the Dungeness crab habitat. In light of the success of direct transmission of $N$. canceri in the laboratory (Childers 1994), the existance of an alternative host is unlikely. Physical differences in estuary characteristics may also affect the prevalence in different locations.

Analysis of the data indicates that when corrected for variation in crab size and sex ratios for the sampling intervals, there was no change in prevalence over the 4 yr period 1990 to 1994 (Table 4) suggesting that the disease is enzootic rather than epizootic. In addition, there does not appear to be a seasonal component to the disease prevalence (Fig. 5), which remained relatively constant between the seasons; the fluctuations which were noted were shown to be associated with variability in the sex ratios of the crabs collected during the different months.

One very striking finding in this study was the marked elevation of infection rate in male crabs as compared to female crabs. Male crabs constituted nearly three-quarters of the infected animals (Table 3 ). In the single instance where the parasite was not detected in the southern part of the geographic range (33 crabs collected from Crescent City Harbor, CA) 2 factors may have influenced the negative results. First, the sample size was small, and secondly, of the 33 crabs, 29 were large females (mean CW $=14.8 \mathrm{~cm}$ ). Thus, the failure to detect the parasite at this location may have been due to the preponderance of large females in the sample.

In the few studies of microsporidian infection prevalences in decapod species where male and female infection prevalences have been reported, the male and female infection levels were approximately equal (Parsons \& Khan 1986, Herbert 1988, Skurdal et al. 1990). The factors involved in generating the difference in infection rate by host sex with Nadelspora canceri are unknown. Possible explanations include behavioral or hormonal differences between males and females. In laboratory experiments, it has been found that crabs can be directly infected with the parasite by consuming infected tissue (Childers 1994). It may be that male crabs are more aggressive than female crabs, and in a cannibalistic species such as Cancer magister (Butler 1954, Tegelberg 1972, Stevens et al. 1982) males may consume more infected crabs than females and thereby incur infections more often. Hormones may also affect the ability of the microsporidian to successfully evade the host immune system or they may inhibit or enhance the growth of the parasite after invasion.

The size range of crabs collected for this study was 0.7 to $18.9 \mathrm{~cm} \mathrm{CW}$, which corresponds to instars 1 through 16 (Pauley et al. 1986). Crabs infected with Nadelspora canceri ranged in size from 2.4 to $16.5 \mathrm{~cm}$ $\mathrm{CW}$. The smallest infected crab which was collected from the Siuslaw estuary in August was probably a 4 th or 5 th instar stage animal which would have metamorphosed from the megalopal stage in April or May (Pauley et al. 1986). Laboratory experiments have indicated that this disease is a chronic one and requires several months before gross signs are detected (Childers 1994). Thus, the crabs could have become infected at or near the post-metamorphosis stage and signs would not have been visible until several molts had occurred. However, the bulk of the infections occurred in crabs in the size range 10 to $13 \mathrm{~cm} \mathrm{CW}$ (25th to 75 th percentiles). Crabs of this size fall within the 1+ age group (Armstrong \& Gunderson 1985, Warner 1987, Gunderson et al. 1990). Infected crabs within the size interval $13-14 \mathrm{~cm} \mathrm{CW}$ had the highest prevalence. Larger crabs had a lower prevalence, with crabs of legal commercial size (>16 cm CW) collected from estuaries rarely infected $(3 / 105)$. This decline in infection rate with size may be due to the high mortality caused by the disease (Childers 1994), which is characteristic of microsporidian diseases (Sprague \& Vávra 1976, Canning 1982). The loss of infected crabs may occur either by direct mortality, by starvation due to a reduction in their ability to capture prey because of muscle degradation, or by an inability to evade predators due to muscle breakdown.

In summary, the results of this study indicate that Nadelspora canceri is widely distributed along the United States Pacific Coast from California to southern Washington, but apparently does not occur further north. Prevalence levels of the disease are high for most estuaries examined. The infection occurs pre- 
dominantly in 1 to $2 \mathrm{yr}$ old crabs ( 9 to $15 \mathrm{~cm} \mathrm{CW}$ ) and is found less often in smaller and larger crabs. Males have a significantly higher rate of infection than do female crabs.

Acknowledgements. This research was supported by Grant No. NA36RG0451 (R/FSD-21) from the National Oceanic and Atmospheric Administration to the Oregon State University Sea Grant College Program and by appropriations made by the Oregon State Legislature. It was also partially supported by Hatfield Marine Science Center Markam Grant, Oregon State University Agriculture Research Foundation Grant 5005, and Oregon Agricultural Experiment Station Project Number ORE00280. We acknowledge Karl Brookins and numerous Hatfield Marine Science Center graduate students for assisting in specimen collection. We thank Dr Thomas Shirley, Deborah Schultz, Erica Leder (University of Alaska, Fairbanks), and Dr James Taggart (National Biological Survey, Glacieı Day îvaliondi Parkj for colieciing and examining crabs from Alaska; and Dr David Sampson (Oregon State University) for providing advice on data analysis. Oregon Agxicultural Experiment Station Technical Paper No. 10676

\section{LITERATURE CITED}

Andreadis TG (1985) Experimental transmission of a microsporidian pathogen from mosquito to an alternate copepod host. Proc natl Acad Sci 82:5574-5577

Armstrong DA, Gunderson DR (1985) The role of estuaries in Dungeness crab early life history: a case study in Grays Harbor, Washington. In: Melteff BR (symposium coordinator) Proceedings of the symposium on Dungeness crab biology and management, 1984. Alaska Sea Grant Report 85-3, Fairbanks, p 145-170

Atkin M, Anderson D, Francis B, Hinde J (1989) Statistical modeling in GLIM. In: Copas JB, Dawid AP, Eagleson GK Silverman BW (eds) Oxford statistical science series. Clarendon Press, Oxford

Butler T (1954) Food of the commercial crab in the Queen Charlotte Islands region. Prog Rep Pacif Coast Stns 99:3-5

Canning EU (1982) An evaluation of protozoal characteristics in relation to biological control of pests. Parasitology 84 $119-149$

Childers RK (1994) Prevalence, geographic distribution, and biology of a dungeness crab, Cancer magister, microsporidian parasite. Master's thesis, Oregon State University, Corvallis

Couch JA (1983) Diseases caused by Protozoa. In: Provenzano AJ Jr (ed) The biology of Crustacea, Vol 6, Pathobiology. Academic Press, New York, p 155-196

Gunderson DR, Armstrong DA, Shi Y, McConnaughey RA (1990) Patterns of estuarine use by juvenile English sole, Parophrys vetulus, and Dungeness crab. Cancer magister. Estuaries 13:59-71

Healy MJR (1988) GLIM: an introduction. Clarendon Press, Oxford

Herbert BW (1988) Infection of Cherax quadricarinatus (Decapoda: Parastacidae) by the microsporidian Thelohania sp. (Microsporidia: Nosematidae). J Fish Dis 11. $301-308$

Morado JF (1993) The morphology, morphogenesis, culture, and pathogenesis of a marine facultative parasitic ciliate, Mesanophrys sp. of the Dungeness crab, Cancer magister. PhD thesis, University of Washington, Seattle
Morado JF, Sparks AK (1988) A review of infectious diseases of the Dungeness crab, Cancer magister. In: Shumway SE (ed) Proceedings of the annual meeting of the National Shellfish Association. J Shellfish Res 7:127

Olson RE, Lannan CA (1984) Prevalence of microsporidian infection in commercially caught pink shrimp Pandalus jordani. J Invertebr Path 43:407-413

Olson RE, Tiekotter KL, Reno PW (1994) Nadelspora canceri n. g., n. sp., an unusual microsporidian parasite of the Dungeness crab, Cancer magister. J Euk Microbiol 4(14): $337-347$

Overstreet RM (1988) Microsporidiosis of the blue crab. In: Sindermann CJ, Lightner DV (eds) Developments in aquaculture and fisheries science, Vol 17, Disease diagnosis and control in North American marine aquaculture. Elsevier, Amsterdam, p 200-202

Overstreet RM, Whatley EC (1975) Prevention of microsporidiosis in the blue crab, with notes on natural infections. In: Avault JW, Miller R (eds) Proceedings of the sixth annual meeting World Mariculture Society. Louisiana State University, Baton Rouge, p 335-355

Parsons DG, Khan RA (1986) Microsporidiosis in northern shrimp, Pandalus borealis. J Invertebr Path 47:74-81

Pauley GB, Armstrong DA, Heun TW (1986) Species profiles: life histories and environmental requirements of coastal fishes and invertebrates (Pacific Northwest) - Dungeness crab. US Fish Wildl Serv Biol Rep 82(1163), US Army Corps of Engineers, TR EL-82-4

Sindermann CJ (1990) Principal diseases of marine fish and shellfish, Vol 2, Diseases of marine shellfish, 2nd edn. Academic Press, New York, p 93-144

Skurdal J, Qvenild T, Taugbøl T, Fjeld E (1990) A 6-year study of Thelohania contejeani parasitism of the noble crayfish, Astacus astacus L.. in Lake Steinsfjorden, S.E. Norway. J Fish Dis 13:411-415

Sparks AK (1985) Synopsis of invertebrate pathology. Elsevier Science Publishers, Amsterdam

Sprague $V(1965)$ Nosema sp. (Microsporidia Nosematidae) in the musculature of the crab Callinectes sapidus. J Protozool 12(1): $66-70$

Sprague V (1970) Some protozoan parasites and hyperparasites in marine decapod crustacea. In: Snieszko SF (ed) A. symposium on diseases of fish and shellfish. Spec Publ 5 , Am Fish Soc, Washington, DC, p 416-430

Sprague $V(1977 a)$ The zoological distribution of Microsporidia. In: Bulla LA Jr, Cheng TC (eds) Comparative pathobiology, Vol 2, Systematics of the Microsporidia. Plenum Press, New York, p 335-386

Sprague $V(1977 b)$ Classification and phylogeny of the microsporidia. In: Bulla LA Jr, Cheng TC (eds) Comparative pathobiology, Vol 2, Systematics of the microsporidia Plenum Press, New York, p 1-30

Sprague V, Vávra J (1976) Preface. In: Bulla LA Jr, Cheng TC (eds) Comparative pathobiology, Vol 1, Biology of the Microsporidia. Plenum Press, New York, p ix-xiii

Stevens BG, Armstrong DA, Cusimano R (1982) Feeding habits of the Dungeness crab, Cancer magjster, as determined by the index of relative importance. Mar Biol 72 $135-145$

Tegelberg H (1972) State of Washington Dungeness crab study, August 1972. Ann Prog Rep US Fish Wildl Serv Project No. 1-76-R, US Fish and Wildlife Service, Washington, DC, p $15-18$

Warner RW (1987) Age and growth of male Dungeness crabs, Cancer magister, in northern California. Calif Fish Game $73: 4-20$

Manuscript first received: February 22, 1995

Revised version accepted: July 24, 1995 